\title{
God's Stopgap: Cardinal Adam Kozłowiecki, S.J.
}

\author{
Robert Danieluk, S.J. \\ Archivum Romanum Societatis Iesu, Rome, Italy \\ arsi-danieluk@sjcuria.org
}

\begin{abstract}
Adam Kozłowiecki (1911-2007) was a Polish Jesuit, who spent sixty-one years in missionary service in Zambia. He arrived there in 1946, just a few months after having been liberated from the concentration camp of Dachau, where he spent the biggest part of his time during wwII (earlier he was one of the first prisoners of the camp in Auschwitz). The vicissitudes made of him a witness of tragedy of the years 1939-45 and a protagonist of the missionary endeavor in Africa - the continent that was then looking for and finding its independence from colonialism. At the same time, Kozłowiecki was both witness and protagonist of the changes in the Catholic Church brought by the Second Vatican Council-the event in which he took an active part as the first archbishop metropolitan of Lusaka. The article, based on the existing literature and archival material from Rome, recalls the life of this extraordinary figure, pointing out the surprises and unexpected changes he had to face several times.
\end{abstract}

\section{Keywords}

Adam Kozłowiecki (1911-2007) - Second Vatican Council - Zambia - Dachau and Auschwitz - Jesuit cardinal - archbishop of Lusaka

Those who were privileged to know Cardinal Kozłowiecki, meet him, or at least talk to him occasionally (as in the case of this author), can certainly remember his extraordinary sense of humor. In his endearing, self-deprecatory manner, he would describe himself as the one used for "filling gaps," i.e. replacing somebody at work. To this end, he used the Polish word zapchajdziura (translated as "stopgap," "placeholder" or "filler") in letters written about his continuous movements and successive assignments in his advanced age. For example, on March 29, 1993 he wrote: "The people say that I have a charism of stopgap. I am 
proud of it. In four years this is already the forth gap that I fill."1 Of course, he was much more than just a stopgap...

The aim of the present article is twofold: to recall Kozłowiecki's life, and to resume the hitherto historiography of this outstanding missionary figure, based in part on his own written words as a way to let his distinctive character shine through.

\section{Kozłowiecki's Life}

Adam Kozłowiecki was born in 1911 in Huta Komorowska (south-east Poland; at that time a part of Austro-Hungary) - the property of his noble family. His father Adam (1874-1949) was a rich landowner and forester. His mother Maria Janocha (1886-1972) was brought up in a very religious family, and thus she wanted a religious education for her three sons. The future Jesuit had one older and one younger brother: Czesław (1909-40) and Jerzy (1914-88).

Since the Kozłowieckis were wealthy enough to provide private primary education for their children, Adam spent the first ten years of life between his native Huta Komorowska and Zakopane (southern border of Poland, in the heart of Tatra Mountains) where his parents had another house. In 1921, he was sent to the famous Jesuit college in Chyrów (today in Ukraine, close to the border with Poland) where he studied until 1926. When his father realized that Adam wanted to enter the Jesuits, he moved him to another school in Poznań (in western Poland), where the future missionary studied until the maturity exams in 1929.

Adam neither forgot the Jesuits nor abandoned his dream of entering the Society of Jesus, despite opposition from his father. In fact, the father's opposition was so strong that the future archbishop of Lusaka took the drastic step of renouncing his heritage by way of official certificate. The father and the son reconciled several years later.

On July 30, 1929, Adam entered the noviciate of the Southern Polish Province (called Provincia Poloniae Minoris at the time) of the Society of Jesus in Stara Wieś (south-east Poland). The usual religious formation followed. After two years in the noviciate, he moved to Cracow to study philosophy, from 1931 to 1933. He was then sent to his own school in Chyrów for one year of the

1 Letter quoted from Adam Kozłowiecki, Moja Afryka, moje Chingombe: Dzieje misjonarza opisane w listach do przyjaciót [My Africa, my Chingombe: A history of a missionary told in letters to friends] (Kraków: Wydawnictwo wAM, 1998), 333. The translation from Polish is mine, as are all other translations in any language other than English quoted in this article, unless it is said differently. 
so-called "regency," which consisted of working as a tutor and educator in that prestigious center. In 1934-38, he studied theology as part of a four-year program in Lublin. According to the practice of the time, he was ordained priest after the third year, on June 24, 1937, in the same town. Once all of his studies were completed, Fr. Adam moved to Lwów (today Lviv, Ukraine) in 1938 for the one-year Jesuit program of spiritual formation called "tertianship" (in Latin tertia probatio). Upon completion of his tertianship in the summer of 1939, he was designated by the superiors to Chyrów to serve as spiritual father at the school he already knew and loved. But the future had made other plans for Fr. Adam. Surely, he could not foresee the world events that would change his life and radically alter his destiny.

When World War II began on September 1, 1939, Kozłowiecki was already in Chyrów. It was a time of confusion and uncertainty, and the Jesuits decided to evacuate the college after the area was bombed several times. Along with several confrères, Adam left for Kochawina (today in Ukraine, south of Lviv) and Tarnopol (today in Ukraine, east from Lviv) on September 9. When Poland was attacked from the east by the Soviet Union (September 17), the refugees split and dispersed. Kozłowiecki decided to go to Cracow. Travelling by any available means of transport, but mostly on foot, and coming face to face with various enemy troops, he finally arrived at the house of his parents and eventually, on October 26, at Cracow. The provincial appointed him minister (responsible for administration and organization) of the large Jesuit community at Kopernika Street. Once again, events not in his control had rerouted him and altered his destiny.

On the morning of November 10, 1939, the Gestapo entered the house and arrested twenty-five Jesuits, among them Kozłowiecki. With his confrères he was brought to the jail at Montelupich Street-his first place of detention, where he remained until February 2, 1940. The Jesuits were not told the reason for their arrest, and - as the future cardinal would later write in his memoirsit was only during transfer to the jail in Wiśnicz (east of Cracow) that a policeman informed him of the real reason for their arrest: the German occupants disliked the Jesuit "philosophy of life" (Weltanschauung). ${ }^{2}$ The future missionary was jailed at Wiśnicz until June 20, 1940—on which day he was transferred to the new concentration camp at Auschwitz. He was one of the first prisoners to arrive at Auschwitz, as evidenced by his number of 1006. His time of "oppression and desolation" as he later called it, continued in Dachau, from December 12, 1940 through April 29, 1945. On that later date, and in another dramatic

2 Adam Kozłowiecki, Ucisk i strapienie, $3^{\text {rd }}$ ed. (Kraków: WAM, 2008), 80. 
turning point, Fr. Adam was freed upon liberation of the Dachau concentration camp by American troops.

Kozłowiecki was one of forty-three Polish Jesuits imprisoned at Dachau; twenty-three of them died. ${ }^{3}$ Those who survived moved from the liberated camp first to Freimann close to Munich on June 5, 1945, and then to the German Jesuits' house in Pullach on June 12. Shortly thereafter, a letter arrived from the vicar general of the Society of Jesus Fr. Norbert de Boynes (1870-1954), saying among other things:

I submit to your consideration the extreme necessity of the Polish workers both in the Rhodesia Mission and in the Chicago house, where at least three Fathers able to work are needed. Your Reverence can speak about this with the Fathers, and let me know their thoughts. In any case do know that my intention is absolutely not to oblige you to one or another of these works, but I am leaving the liberty of choice to the Fathers. ${ }^{4}$

De Boynes's invitation was not a general request for missionaries somewhere on the Black Continent but was meant specifically for the mission in Northern Rhodesia that had been under the responsibility of the Polish Jesuits since 1912. The vicissitudes of life during two world wars had made it impossible for the Poles to send new missionaries and other types of help to that mission, which operated with great difficulty as a result.

Five Polish Jesuits answered the request and offered to join the African mission; among them was Kozłowiecki, who in fact would be the first to reach the new destination. ${ }^{5}$

On July 12, 1945, he left for Rome and arrived three days later. He spent the next several months in the Eternal City, serving as spiritual father to the Polish scholastics studying there. At the same time, he was preparing for his departure to Africa.

3 Encyklopedia wiedzy o jezuitach na ziemiach Polski i Litwy 1564-1995, 2 ${ }^{\text {nd }}$ ed. [hereafter Encyklopedia wiedzy o jezuitach), ed. Ludwik Grzebień et al. (Kraków: Wyższa Szkoła FilozoficznoPedagogiczna Ignatianum/Wydawnictwo WAM), 117 .

4 ARsi, Registri Poloniae Minoris II, 376 (copy of that letter, addressed June 19, 1945 to Józef Krzyszkowski-one of the Jesuits who survived Dachau; on him, see Encyklopedia wiedzy o jezuitach, 338). Norbert de Boynes, French, Jesuit since 1888, was the assistant of Father General in 1923-44 and then became vicar general of the Society; as such he lead the order until 1946 when Fr. Janssens was elected general (Dictionnaire du monde religieux dans la France contemporaine, vol. 1: Les jésuites, ed. Paul Duclos (Paris: Beauchesne, 1985, 55-56).

5 Kozłowiecki, Ucisk i strapienie, 565. Other volunteers were: Wincenty Cichecki, Stanisław Nowicki, Julian Pławecki, and Piotr Świerczek. On them, see Encyklopedia wiedzy ojezuitach, 98, $463,517,678$. 
This preparation was not simply a matter of bureaucracy, the difficulties of obtaining a passport and the necessary authorization from British authorities to enter Rhodesia aside. More important was the delicate subject of his internal disposition and feelings about the new mission. His letters from this period indicate that he was homesick for his native country and wanted to work in Poland, preferably with young people as he was supposed to have done in Chyrów. It is apparent from his correspondence that Fr. Adam paid a heavy emotional price for abandoning his dream of returning to Poland to pick up where he had left off in 1939."You know how much I was attached to Chyrów" he was writing from Rome to Fr. Teofil Bzowski (1873-1959) November 16, 1945,

and how much I loved my homeland. I was teared out from it in a moment that was for me the most difficult. Yet, during all these long years in the camps, with my thoughts I was living in Poland, I was dreaming about it and dying for it - that was what I was allowed to. Every night I was moving to these beloved places: Chyrów, Stara Wieś, Lwów, Zakopane, Kraków, Lublin, Poznań [...]. Sometimes when I had monotonous and thoughtless work, I could pray and dream the entire day. In thoughts, I moved to Stara Wieś, Chyrów [...] and today? God wants me to abandon all that, for I do not even dare to think about coming back. That I was allowed when I was in the camps. Today, I cannot even in thoughts travel there, because this arouses in my heart an insupportable homesickness and rebellion. Today, I am not even able to enjoy a nice landscape, because I immediately realize that this is not Poland. This Poland is beautiful, even more beautiful! I only desire that death delivers me from that suffering. ${ }^{6}$

Furthermore, the fact that his family was very much affected by the war must have contributed to such feelings: his brother Czesław was shot in 1940 after having been arrested during an attempt to cross the border in hopes of joining the Polish army abroad. The other brother, Jerzy, who served with Polish troops in France, relocated to Canada after the war. His parents lost their property at the beginning of the war but were not given it back under the new government. In fact, his father Adam was arrested and spent some time in a communist-run jail. These experiences certainly did not make the future cardinal's decision to join the Africa mission any easier. Yet, in a show of strength of character, he complied with the vicar general's request and accepted the invitation to

6 Letter quoted in: Kozłowiecki, Moja Afryka, 13. Bzowski, Jesuit since 1893, had worked in Chyrów since 1897 (Encyklopedia wiedzy o jezuitach, 83). 
proceed to the African mission-a decision he never regretted as he later confessed many times.

In the meantime, Kozłowiecki professed his final vows on August 15, 1945 at the altar of Saint Ignatius in the Roman Gesù Church. ${ }^{7}$ With all formalities now behind him, Adam sailed from Naples to Durban (South Africa) at the end of January 1946. Then, after a journey by train from Johannesburg, in April of the same year, he finally arrived at Monze (circa $196 \mathrm{~km}$ south-west from Lusaka), and shortly thereafter at Kasisi ( $24 \mathrm{~km}$ north-east from Lusaka) — his first African destination.

In a letter written from Kasisi to Fr. Assistant Anton Prešeren (1883-1965) on August 19, 1946, Fr. Adam shared the various difficulties he was experiencing in the mission, including the strain of overseeing as "school manager" ten separate schools, only two of which were in Kasisi and the others as far away as sixty miles. ${ }^{8}$ Additionally, he did not have time to learn the local language (lenje), and could communicate with teachers and students only in English, limiting his effectiveness. Aware of the immensity of the task that he was charged with, he often felt very tired, but not discouraged. Adding to his woes were the individualism and even eccentricity exhibited by some of the missionaries. This indeed was one of his biggest headaches. In this very first letter written by Fr. Adam, the first among those preserved in the Jesuit Roman Archives, he stated what would become a constant refrain in his missives to superiors and confrères over the years: the appeal for new missionaries.

From 1946 through 1950, Kozłowiecki was anchored to this particular missionary station. His responsibility extended to not only overseeing schools, but to direct pastoral work in some three hundred villages in the area of Kasisi. From 1948, he was also superior of the Jesuit community. "My friends know in what mood I was leaving. Yet, today, in front of so much work to do here, I would not dare to come back to my country, even if I were allowed"-he confessed in May 1947, after his first year there. ${ }^{9}$

He left Kasisi in $195^{\circ}$ after being appointed by the Vatican as administrator of the new Apostolic Vicariate of Lusaka, which was created from the already

7 See their formula in ARSI, Assistentia Europae Orientalis: Ultima vota 7 , fol. $5^{6^{r}}$. The archives keep also his formula of the renunciation of goods, which accompanies the final vows, see ARSI, Assistentia Slavica. Ultima vota 3 , fol. $121^{\mathrm{r}}$.

8 ARSI, Missio Lusakensis 1002-VII-2. Anton Prešeren, Slovenian, Jesuit from 1910, since $193^{1}$ was the general's assistant for the Slavic provinces of the Society (Diccionario histórico de la Compañía de Jesús: Biográfico-temático [hereafter $D H C J$ ], 4 vols. [Rome: Institutum Historicum S.I. - Madrid: Universidad Pontificia Comillas, 2001], 4:3228-29).

9 Letter (addressed to the periodical Postaniec Serca Jezusowego) quoted in Kozłowiecki, Moja Afryka, 19 . 
existing Apostolic Prefecture. ${ }^{10}$ That meant for Kozłowiecki a change of address from Kasisi to Lusaka and more work due to his replacement of Bruno Wolnik (1882-1960) as the leader of the entire mission entrusted to the Polish Jesuits in this part of what was then Northern Rhodesia. ${ }^{11}$

Thus, he was headquartered in Lusaka from 1950 to 1955, though he was often not there; traveling from one missionary station to another was a necessity. And in 1955, he undertook a long work-related journey abroad, traveling throughout Europe and the United States to promote the mission and to seek assistance for his initiatives.

That same year, 1955, brought an important event that would again change the rest of Fr. Adam's life: he was elevated to bishop and appointed apostolic vicar of Lusaka. ${ }^{12}$ It was in that city that his episcopal consecration took place, on September 11, 1955. As the first bishop of Lusaka, which was not yet a regular diocese, Kozłowiecki's titular diocese was Diospolis Inferior (in partibus; today in Egypt in the area of the Nile delta), while his motto In nomine Domini was suggested to him by Pius XII (r.1939-58) himself, during an audience in 1955 .

Four years later, when the next pope, John XXIII (r.1958-63), decided to establish a regular ecclesiastical structure in today's Zambia elevating its capital to the rank of archdiocese (with seven suffragan dioceses and prefectures), he appointed Kozłowiecki archbishop metropolitan of Lusaka on April 25, 1959. ${ }^{13}$ Installed on July 12, 1959, Kozłowiecki held that post for ten years, retiring in May 1969; he was succeeded by the African Emmanuel Milingo (1930- ; in office 1969-83), who in 2006 would be excommunicated.

This retirement however did not mean a perpetual holiday. Indeed, Kozłowiecki remained in Zambia, returning to pastoral work as a simple missionary, which was in fact his favorite activity. Of course, he often administered the sacraments in his role as bishop, and as a retired archbishop, he continued to have a titular diocese, this time in Potenza Picena, Italy. He dedicated the rest of his life to pastoral work in different communities: Chingombe $(c .268 \mathrm{~km}$ north-east from Lusaka; 1970-73 and 1976-89), Mumbwa (c.150 km north-west from Lusaka; 1973-74), Chikuni (c.224 km south-west from Lusaka; 1975-76), Lusaka (1989-90), Mulungushi (c.150 km north from Lusaka; 1990-92), and Mpunde (c.182 km north-west from Lusaka; 1992-2007). Certainly, this part of Fr. Adam's résumé justifies his humorously self-described role of "filling gaps"!

\footnotetext{
$10 \quad$ Acta Apostolicae Sedis 43 (1951): 100-1.

11 Bruno Wolnik from Poland, a Jesuit since 1899, left for Africa in 1925 and two years later was appointed first apostolic prefect of Broken Hill (Encyklopedia wiedzy o jezuitach, 756-57).

12 Acta Apostolicae Sedis 37 (1955): 616.

13 Acta Apostolicae Sedis 51 (1959): 793-96.
} 
During all of these years, first as bishop, then as archbishop, but also after 1969, he travelled abroad many times. Primarily, he was required to attend meetings of bishops in Africa and Rome, as well as work in different organizations and Vatican dicasteries. Such travels continued and even increased after his retirement: in 1961, he was elected chair of the Association of Member Episcopal Conferences in Eastern Africa; and in 1971-91, he served as national director of the Pontifical Missionary Works for Zambia, and (since 1970) the member of the Congregation for the Evangelization of Peoples (Propaganda Fide). Besides that, in 1967-94, he participated in several synods of bishops in Rome.

Only in 1970 did he travel to Poland for the first time since leaving in 1940, but he later visited his native country several times, accompanying John Paul II (r.1978-2005) on some of the pope's pastoral visits. Kozłowiecki made a point of visiting his native region of Poland, particularly his birthplace, where he was always warmly welcomed.

An important chapter of Kozłowiecki's life was quite clearly-his participation in the Second Vatican Council (1962-65). The Vatican Archives preserve and make available for research the documentation of this extraordinary event that changed the church so radically. As one can see in the inventories of the series "Concilium Vaticanum II,"14 the documents related to Kozłowiecki's activities at the council are found in many archival units (the so-called buste) of that series. ${ }^{15}$ These inventories provide detailed lists, though few of these documents have been published. ${ }^{16}$ The records show that the archbishop of Lusaka participated in some of the most important issues debated by the council such as the nature of the church, its place in the contemporary world, its missionary activity, and the role of lay people in the church; the role of bishops, priests, and religious; ecumenism; and religious freedom.

His published texts from the time of the council confirm what he wrote on February 12, 1977, in the foreword to the edition of his letters, confessing that Vatican II was for him a time of opening his eyes and heart, especially with regard to his perception of ecumenism as problematic:

\footnotetext{
14 Archivum Apostolicum Vaticanum (hereafter AAV), Indici $1198 \mathrm{I}-\mathrm{V}, \mathrm{VII}, \mathrm{XVIII}, \mathrm{XX}$.

15 AAV, Conc. Vat. II 2, 5, 11-2, 21, 43, 65, 95, 120, 131-32, 143, 145, 147, 149-50, 156, 186-89, 19596, 198-200, 203, 225-7, 230, 233, 235-36, 243-47, 249-50, 338, 346, 1434, 1448, 1602, 1610, $1625,1630,1652,1705,1744$.

16 Acta Synodalia Sacrosancti Concilii Oecumenici Vaticani II, 35 vols. ([s.l.]: Typis Polyglottis Vaticanis, 1970-99). The texts of Kozłowiecki are in following volumes of these Acta: I/1 [1970], 421-23; I/2 [1970], 171-72; I/3 [1971], 511-12; I/4 [1971], 208-12; II/1 [1971], 677-80; II/3 [1972], 160-64; II/4 [1972], 240-44; III/4 [1974], 122-24; III/5 [1975], 477; III/7 [1975], 628-31; IV/1 [1976], 426-28; vi/2 [1997], 354; Appendix [1983], 645-46. For the details of Kozłowiecki's activity during the council, see the index of that series: Acta Synodalia Sacrosancti Concilii Oecumenici Vaticani II: Indices ([s.l.]: Typis Polyglottis Vaticanis, 1980), 542 .
} 
Today, I am very much ashamed of the not-ecumenical attitude, especially during the first years of my missionary work. On the other hand, I was sent to a station, which was treated by the missions of other confessions in a not very ecumenical spirit, but even this does not justify the lack of charity. Finally, it was necessary that the Second Vatican Council come to open my eyes and [...] my heart. ${ }^{17}$

The issue of ecumenism as problematic was multidimensional. During preparation for the conciliar meetings, on August 2, 1959, Kozłowiecki sent to Rome his comments concerning the interpretation of various canons of the canon law, especially regarding ecclesiastical communion and the fact that sometimes the Catholics could or even should pray together with Christians of other communities, and that this was not compromising their Catholic orthodoxy. ${ }^{18}$

Later, during the council, he would return to the theme of unity of the church arguing that it was something deeper and much more complex than merely retaining Latin as the liturgical language:

If I am allowed to say — and it has already been said — we often hear that Latin is the language of the Catholic Church. But the question should be asked, whether only Latin is the language of the Catholic Church. What about Greek, Syriac, Arabic, Slavonic? What about modern languages? We have to be careful that, while singing praise of Latin, we do not offend other languages, including liturgical languages. [...] The unity of the Church and of all peoples is to be promoted, but the true unity needs more solid bases than just a liturgical language. These bases are consciousness that we all are one body in Christ, and the unity of this body is preserved by the supreme law and the first and the highest commandment, i. e. the commandment of love and charity. The most cruel wars of the last century show that the unity of the liturgical language did not produced in the Western Church the real unity, which is the unity of hearts. ${ }^{19}$

Of course, the archbishop of Lusaka could hardly be called revolutionary or radical in his proposals for reform and necessary adaptation of the church. In

17 Ludwik Grzebień and Adam Kozłowiecki, Wsród ludu Zambii, vol. 2: Listy z misyjnego frontu [Letters from the missionary front] (Kraków: Wydawnictwo Apostolstwa Modlitwy, 1977), 5 .

Acta et documenta Concilio Oecumenico Vaticano II apparando, Series 1: Antepraeparatoria, vol. 2: Consilia et vota episcoporum et praelatorum, pars 5: Africa ([s.l.]: Typis Polyglottis Vaticanis, 1960), 412-13.

Acta I/1 [1970], 422. 
his comments on religious liberty, he stressed the need for distinguishing between true freedom and false ideas pertaining to it. He believed there were two sources of possible errors concerning that point: one, the abuse of the authority oppressing the religious liberty; and two, the abuse of freedom understood as total independence including arbitrariness and dissolution. ${ }^{20}$

Kozłowiecki's intuitions, ideas, and proposals were certainly based on his life experience and missionary work. Though not one of the leading figures of Vatican II, his proposals dealt with real life, specifically life in Africa, and the problems discussed in the conciliar aula. He also intervened when he believed it was necessary to notice, comment on, or propose ideas that would promote reform of the church. Thus, his contributions concern such points as diverse as whether the catechists could administer some sacramentalia to Catholics or ways of being (including the way of dressing) of the priests and bishops. ${ }^{21}$ One can extrapolate from his texts that he was generally in favor of transparency (including in what concerns the sustainment of the clergy) and simplicity, also in what concerned the language of the conciliar documents:

It is true that our way of speaking should be the one of the Church teaching solemnly. Yet it means neither that the language of the conciliar decrees should be difficult and complicated, nor that the periods have to be long, with many additions and conclusions. Let's come back to a language and stile characterized by depth, clearness, and simplicity. Such language will not only be easily understood by everybody, but also - if I am not mistaking - is the language closest to the one that used Christ himself and the Apostles. ${ }^{22}$

Despite the seriousness of the issues under debate, the future cardinal could not resist interjecting a bit of humor. "I do not consider myself successor of one of the wiser Apostles like John or Matthew, but maybe as successor of Bartholomew who neither wrote a Gospel nor even an epistle," he said on November 26, 1962, speaking in the aula, while a few days later, on December 3, 1962, he started his speech by saying, "I know two things about Saint Bartholomew: the first is that he did not write anything, the second that he was skinned. In order to avoid the latter, I shall speak shortly!"23

One may also presume that his participation in conciliar meetings and discussions was not the only reason Kozłowiecki was noticed by the then-young

\footnotetext{
$20 \quad$ Acta $\mathrm{IV} / \mathbf{1}[1976], 426-28$.

21 Acta I/2 [1970], 171-72. Acta Synodalia: Appendix [1983], 645-46.

22 Acta I/4 [1971], 208. AAV, Conc. Vat. II, busta 12, fasc. 16, fols. 96 and 100.

23 Acta I/3 [1971], 512. Acta I/4 [1971], 208.
} 
bishop of Cracow, who would later (February 21, 1998) name him as cardinal. This dignity was first and foremost an acknowledgment of the multiple achievements of a missionary and bishop who had dedicated his life to his new home country and its people. For the same reason he received several state decorations from Zambia, Poland, and France, as well as two doctorates honoris causa: one from the Catholic University of Eastern Africa (Nairobi, Kenya), and another from the Cardinal Stefan Wyszyński University (Warsaw, Poland).

Cardinal Adam Kozłowiecki died on September 28, 2007 in the hospital in Lusaka and was buried close to the cathedral church of the Zambian capital.

The list of his achievements in their entirety would be too long to discuss here. He contributed greatly to the consolidation and development of the mission, which was experiencing difficulty when he first arrived in 1946. He invigorated the mission through exemplary leadership at many different levels, successes that elevated him from the post of simple missionary to cardinal. He strengthened local ecclesiastical structures not only by building new churches, chapels, and schools, but also by adding new missionaries and providing other necessary help for Zambia. He also promoted the formation of the local clergy by initiating in $195^{2}$ a minor seminary in Mpima (c.112 km north-east from Lusaka) and, in 1954, the novitiate for the sisters from the Polish Congregation of Little Servants of Mary Immaculate (collaborating with the Jesuits in the Zambian Mission since 1928) in Karenda (c.234 km north-west from Lusaka). As archbishop he insisted many times that his replacement should be a local prelate. He founded a local religious women's congregation on diocesan law: Handmaids of the Blessed Virgin Mary (1961). He was not only in favor of "Zambianization" of the church but supported political independence for Zambia and participation by Africans in its government. He issued statements against racism that were warmly welcomed by some and criticized by others; for example, in 1956, he insisted that a Catholic school for whites accept an Indian girl (unusual at that time!). He was willing to roll up his sleeves and address the social problems of a country for which he shared its hopes and concerns. The accomplishments of this tireless, selfless, and supremely talented missionary are simply the keywords of Kozłowiecki's sixty-one-year career in Zambian church and civil society. At present, serious steps are being taken in Zambia, Poland, and Rome, to evaluate the possibility of opening the process of beatification.

The hitherto literature on Kozłowiecki exists mostly in Polish. Surprisingly as it may seem, the author of the main Jesuit bibliography of the last century, László 
Polgár (1920-2001), does not even include him in the third part of his repertory. To find the name of this Jesuit missionary one must consult the appendices of Polgár's bibliography published in the periodical Archivum historicum Societatis Iesu in 1999-2000, which mention only an edition of Kozłowiecki's letters and one article about him. ${ }^{24} \mathrm{~A}$ few other titles appear in the same appendices from the years 2007-17, edited by Paul Begheyn. ${ }^{25}$ Altogether, this repertory lists only two books authored by the first archbishop of Lusaka and three articles and one book about him. The bibliography of Ludwik Grzebień completes these data listing seventeen titles including books, articles, and dictionary entries authored by or concerning the cardinal. ${ }^{26}$ With the exception of one, all are in Polish. ${ }^{27}$

The fact that there is no biographical article about Kozłowiecki in the historical dictionary of the Society of Jesus published in 2001 in Spanish ${ }^{28}$ is understandable if we remember that it does not include articles about persons living at the time of publication. Whatever were the criteria of the recent Cambridge Jesuit encyclopedia, it also has no article about this outstanding missionary figure, though he is mentioned in the article about Zambia-Malawi. ${ }^{29}$ The reader of the Polish repertories will be happy to find biographical notes about him both in the Jesuit encyclopedia first published in 1996 and in the

24 László Polgár, Bibliographie sur l'histoire de la Compagnie de Jésus, 1901-1980, vol. $3^{* *}$ : Les personnes; Europe (Rome: Institutum Historicum Societatis Iesu, 1990), 331; AHSI 68 (1999): 433 (listing: Kozłowiecki, Moja Afryka); A HSI 69 (2000): 375 (listing: Janusz Gajda, "En el camino misionero: Sesenta años de sacerdocio del arzobispo Adam Kozlowiecki S.I.," Omnis terra 30 [1998]: 106-12).

25 AHSI 78 (2007): 440 (listing: Irena Kadłubowska, Od hrabiego do misjonarza: Adam Kozłowiecki TJ, życie i dzieto [Warsaw: Laguna, 2002]); AHSI 84 (2015): 403 (listing: Stanisław Cieślak, "Auf der Suche nach Versöhnung. Kardinal Adam Kozłowieckis Erinnerungen an seine Zeit im KZ Dachau," Stimmen der Zeit 6 [2012]: 397-408); AHSI 85 (2016): 514 (listing: Cieślak, "Kardynał Adam Kozłowiecki SJ [1911-2007] i papież św. Jan Paweł II [1920-2005]," Studia paedagogica Ignatiana: Rocznik Wydziatu Pedagogicznego Akademii Ignatianum w Krakowie 17 [2014]: 89-103, and Not und Bedrängnis: Als Jesuit in Auschwitz und Dachau; Lagertagebuch [Regensburg: Verlag Friedrich Pustet, 2016] — the latter listed also in AHSI 86 [2017]: 504).

26 Ludwik Grzebień, Podstawowa bibliografia do dziejów Towarzystwa Jezusowego w Polsce, vol. 2. (Kraków: Wydawnictwo WAm/Wyższa Szkoła Filozoficzno-Pedagogiczna Ignatianum, 2009), 127-29.

27 The exception is Janusz Gajda, "On the Mission Road: 6o Years of Priesthood of Archbishop Adam Kozłowiecki SJ," Omnis terra 32 (1998): 106-12 (the Spanish version of the same article is listed by Polgár in 2000 as said above; it exists also in Portuguese and in French, published by the same periodical).

28 DHCJ.

29 Edward P. Murphy, "Zambia-Malawi," in The Cambridge Encyclopedia of the Jesuits, ed. Thomas Worcester (New York: Cambridge University Press, 2017), 853-54. 
more general Catholic encyclopedia edited in 1973-2014 at the Catholic University of Lublin as well as in some other similar publications. ${ }^{30}$

Other than these biographical entries, several articles about him authored by Stanisław Cieślak, who writes mostly in Polish, were published in the years following the death of the cardinal. ${ }^{31}$ The articles in other languages are substantially less numerous. ${ }^{32}$

If one would like to read a more extensive biography of Kozłowiecki, two books published between 2002 and 2009 by Cieślak and Kadłubowska could be of help. ${ }^{33}$ Both complement and update the older monograph by Grzebień,

30 Encyklopedia wiedzy o jezuitach, 315; Encyklopedia katolicka (Lublin: Towarzystwo Naukowe Katolickiego Uniwersytetu Lubelskiego, 2002), 9:1111-12; Agata i Zbigniew Judyccy, Polonia: Stownik biograficzny (Warsaw: Wydawnictwo Naukowe PWN, 200o), 155-56; Agata i Zbigniew Judyccy, W stużbie Bogu i światu: Stownik biograficzny; Polscy i polskiego pochodzenia kaptani, zakonnicy i siostry zakonne petniacy postugę w różnych krajach świata; Anno Domini 2002 (Toruń: Oficyna Wydawnicza Kucharski, 2002), 133-34; Krzysztof Rafał Prokop, Polscy kardynatowie (Kraków: WAM, 2001), 371-81; Encyklopedia polskiej emigracji i Polonii, ed. Kazimierz Dopierała (Toruń: Oficyna Wydawnicza Kucharski, 2004), 3:37-38.

31 Besides the above quoted articles by Cieślak, he also authored, among others:

- "Misjonarz Afryki śp. ks. kard. Adam Kozłowiecki SJ (1911-2007)," Rocznik Wydziału Pedagogicznego Wyższej Szkoty Filozoficzno-Pedagogicznej Ignatianum w Krakowie 2007 (2007): 85-113;

- "Z polskiej ziemi... Miłość Ojczyzny w życiu ks. kard. Adama Kozłowieckiego SJ (19112007)," Rocznik Wydziatu Pedagogicznego Wyższej Szkoty Filozoficzno-Pedagogicznej Ignatianum w Krakowie 2009 (2009): 203-20;

- "Wspomnienia ks. Kard. Adama Kozłowieckiego SJ z Dachau," Rocznik Wydziatu Pedagogicznego Akademii Ignatianum w Krakowie 2011 (2011): 131-49;

- "Być porządnym człowiekiem: Posługa miłosierdzia kard. Adama Kozłowieckiego SJ," Życie duchowe 76 (2013): 72-78;

- "Ks. kard. Adam Kozłowiecki SJ (1911-2007) Misjonarz Afryki," Studia sandomierskie 21 (2014): 169-87;

- "Ks. arcybiskup Adam Kozłowiecki SJ w obozie koncentracyjnym w Dachau w 1972 roku," Nasza przesztość 127 (2017): 221-40;

- "Ks. kard. Adam Kozłowiecki SJ (1911-2007): W 10. rocznicę śmierci," Ignatianum: Pótrocznik Akademii Ignatianum w Krakowie 2 (2017): 26-27;

- "Kardynał Adam Kozłowiecki SJ: Kapłan, więzień obozów koncentracyjnych, misjonarz," in W imię Pana: Kardynat Adam Koztowiecki SJ, ed. Daniel Koryciński (Huta Komorowska: Muzeum Kardynała Adama Kozłowieckiego SJ, 2017), 15-46.

32 Besides those by Cieślak and Gajda quoted in the footnotes above, there is also an Italian contribution of Marek Inglot 'So per quale motivo soffro': Card. Adam Kozłowiecki SJ (1911-2007); Prigioniero dei campi nazisti, missionario - arcivescovo," in Perseguitati per la fede: Le vittime del Nazionalsocialismo in Europa centro-orientale, ed. Jan Mikrut (San Pietro in Cariano: Gabrielli Editori, 2019), 663-80.

33 Stanisław Cieślak, Kardynat Adam Kozłowiecki (Kraków: Wydawnictwo wam, 2008; 2nd ed. 2009); Irena Kadłubowska, Od hrabiego do misjonarza: Adam Koztowiecki TJ, życie i dzieto (Warszawa: Laguna, 2002). 
Wśród ludu Zambii (Among the people of Zambia), which remains up to the present the best and the most complete history of the mission run by the Polish Jesuits in Zambia. ${ }^{34}$ For obvious reasons, one part of it deals with the cardinal and thus should be read by those who are interested in his biography. For the same reason other studies about the history of the mission are of interest and should be quoted here. ${ }^{35}$

To sum up: most of the literature concerning Kozłowiecki exists in the form of biographical articles and entries in dictionaries and encyclopedias. With a few exceptions, they all are written in Polish.

It is necessary to mention here the activities of the foundation called Heart without Frontiers, which originated in 2008 and which is based in Majdan Królewski (southern-eastern Poland, close to Huta Komorowska - the birthplace of the cardinal where a special museum was opened in 2011), whose purpose is to cultivate the memory of Kozłowiecki through the promotion of conferences, publications, and exhibits. ${ }^{36}$

As for publications authored by the cardinal himself, his best-known work is undoubtedly his memoir of time spent in the concentration camps, Ucisk $i$ strapienie (Oppression and desolation), written shortly after the war, but not published until 1967. It was republished three times between 1995 and 2012 in a full and uncensored version, unlike the first edition. ${ }^{37}$ In 2016, a German translation of it was published under the title, Not und Bedrängnis: Als Jesuit in Auschwitz und Dachau; Lagertagebuch. ${ }^{38}$

Other known publications are two volumes edited by Grzebień in 1977 and in 2008, containing the selected letters from Kozłowiecki's immense correspondence; both are in Polish. ${ }^{39}$ Besides that, there are some articles and volatile printings that he published. Several examples of the former are to be found in the periodical Postaniec Serca Jezusowego (Messenger of the Sacred Heart of

34 Ludwik Grzebień and Adam Kozłowiecki, Wsród ludu Zambii, vol. 1: Pionierski trud misjonarzy stowiańskich 1881-1969 (Kraków: Wydawnictwo Apostolstwa Modlitwy, 1977). The English-speaking reader will appreciate the summary in that text at pp. 371-89.

35 Edward P. Murphy, A History of the Jesuits in Zambia: A Mission Becomes a Province (Nairobi: Paulines Publications Africa, 2003); Ludwik Grzebień, "Misja jezuitów polskich w Afryce," in Maria Teresa Ledóchowska i misje, ed. Bohdan Bejze, Józef Gucwa, and Antoni Koszorz (Warszawa: Wydawnictwo Sióstr Loretanek, 1977), 339-64.

36 See the web page of the foundation, http://www.cardinalekozlowiecki.pl/ (accessed April 4, 2020).

37 Adam Kozłowiecki, Ucisk $i$ strapienie, $3^{\text {rd }}$ (additional) ed. (Kraków: Wydawnictwo wam, 2012). All previous editions had been published by the same publishing house: the first in 1967 (the full title was Ucisk i strapienie: Pamiętnik więźnia 1939-1945 [Oppression and desolation: memories of a prisoner, 1939-1945]), the second in 1995, and the third in 2008.

38 Regensburg: Verlag Friedrich Pustet.

39 Grzebień and Kozłowiecki, Wsród ludu Zambii, vol. 2. Kozłowiecki, Moja Afryka. 
Jesus) or missionary periodicals edited by the Polish Jesuits in Chicago under the titles that changed through the years (in 1951-53 it was Polonia, in 1953-66 Pionierski trud, and later Wśród ludu Zambii), where Kozłowiecki was often asking for financial help necessary for his work (ex. gr. the article in Postaniec from 1948 under the all-saying title "Jestem bez grosza" [I am without a penny].$^{40}$ An example of the latter instead is the booklet In the Wilds of N. Rhodesia (Chicago, 1953) or his Pastoral Letter of the Archbishop of Lusaka, 1960-a twenty-five-page booklet with the letter signed January 22, 1960 and addressed to the clergy and the faithful of his archdiocese in order to call all to their common responsibility for the church.

Kozłowiecki was too busy to continue his writing. The editor of his letters and co-author of the monograph Wśród ludu Zambii, Grzebien, recalls that he tried to persuade Fr. Adam to write a memoir similar to the one recounting his war experiences, which he had prepared following an order from his superiors. ${ }^{41}$ In 1977, the then-archbishop emeritus himself mentioned these invitations and suggestions, confessing that he tried to put them into practice, but without success, because of his activities that left him no time for writing. In the foreword to the edition of his letters, he recalls: "From time to time I was asked to prepare my memories and reflections from thirty years of work in Africa. I even started to write, but the lack of time obliged me always to interrupt this work. I was then asked to give permission to publish my letters."42

This proved to be a very wise suggestion, since the correspondence of the first archbishop of Lusaka is huge (according to Grzebień, it may count up to 100,00o letters). ${ }^{43}$ Thanks to both volumes mentioned above (in fact they are like the cardinal's autobiography), we have 345 letters written by Kozłowiecki between 1945 and 1997, available in their original Polish. Besides that, there are many other letters that he wrote and received from his more than three thousand correspondents worldwide. ${ }^{44}$ They are preserved in the Jesuit archives in Lusaka and in Cracow. Another collection of his letters is kept in the Jesuit Roman Archives-Archivum Romanum Societatis Iesu.

40 Quoted in Grzebień and Kozłowiecki, Wsród ludu Zambii, 1:161.

41 Grzebień and Kozłowiecki, Wsród ludu Zambii, 2:8. Kozłowiecki, Moja Afryka, 7. Serce bez granic: Apostot Afryki, obywatel świata, rodak z Huty Komorowskiej; Ks. kard. Adam Kozłowiecki SJ 1911-2007 (Sandomierz: Wydawnictwo Diecezjalne i Drukarnia w Sandomierzu, [2012]), 210.

42 Grzebień and Kozłowiecki, Wsród ludu Zambii, 2:5.

43 Kozłowiecki, Moja Afryka, 5.

44 That number of the cardinal's correspondents gives the inventory of the Jesuit archives in Cracow, while the catalogue of the exhibition dedicated to him: In nomine Domini: Missionario dell'Africa Cardinale Adam Koztowiecki (1911-2007) (Rome: Fondazione Cardinale Adam Kozłowiecki "Cuore senza Frontiere," 2017), 12, speaks about more than 1,6oo correspondents. 
When Ludwik Grzebien was preparing his monograph Wśród ludu Zambii, Kozłowiecki suggested to him that it would be of great help, if he could use the Roman archives of the Propaganda Fide and those of the Jesuit General Curia. Unfortunately, it was not possible because in the 1970s the material from that time was not yet available for consultation. ${ }^{45}$

Recently, ARSI has followed the example of the Vatican Archives, which, as a result of a decision of Pope Francis (r.2013-), had opened to scholars all documents until the death of Pope Pius XII (October 1958). This means that the considerable part of Kozłowiecki's correspondence preserved in ARSI, i.e. 161 of his 217 letters (mostly originals - taped and handwritten - that he addressed to the Society's superior general, his assistants or some other Jesuits from the curia) and several dozens of copies of answers to these letters sent to him from the order's Roman headquarters as well as those written by some other Jesuits are accessible for consultation-approximately half of all ARSI documents concerning him. Until there is a detailed inventory, an evaluation of this collection is not possible.

Returning to Kozłowiecki's letters, those both published and unpublished are instructive in many respects. They do not only round out the cardinal's biography that we know from the above-quoted literature, but they also reveal characteristic features of his personality.

Several points emerge. One of them is certainly the feeling of being overwhelmed by the amount of work required of him. Very quickly after his arrival in Africa, the young missionary realized how much was to be done there. It bothered him to realize that the quantity of tasks to accomplish was influencing the quality of work. With regard to this, he quoted several times the circular letter on spiritual life that Fr. General Jan Baptist Janssens (in office 1946-64) addressed to all Jesuits on December 27, 1946. Among many considerations, the one that stressed the necessity of maintaining the quality of ministries over assuming too much work says: "At this time, let's our distinctiveness be: Not a lot, but very much."46 What Kozłowiecki was experiencing was the opposite: he felt that he and other missionaries were doing too many things and thus were not able to provide good quality ministry to the people. On August 17, 1948, he shared this feeling with Józef Cudziński (1905-90), a Polish Jesuit working at that time in the General Curia in Rome:

\footnotetext{
45 Robert Danieluk, "From Failure to Success: The Jesuit Mission in Zambia and the Sources for Its History in the Jesuit Roman Archives," AHSI 88 (2019): 419-38.

46 "Sit his temporibus nostra tessera: Non multa sed multum" (Acta Romana Societatis Iesu XI, no. 2 [1946]: 157).
} 
I would not even start to write a long letter, if not because I take it as my duty to alarm the brain and the heart of the Society. [...] A month ago, I read the letter of Father General about the spiritual life, and I am deeply impressed by it. This letter is a big condemnation of all we are living here, but we are in such a disastrous conditions that it is physically impossible to put in practice the indications that this letter contains. Non multa sed multum. But we are catastrophically too few in number to respect this wise advice. It would have been necessary to close two thirds (I am not exaggerating) of our Mission and neglect the fields poured with the sweat of our predecessors. ${ }^{47}$

Looking at his published letters, one can see that from the first one (July 29, 1945) up to the last one (April 1997), ${ }^{48}$ Kozłowiecki stressed the immensity of work to be done; this was a key motive of his correspondence. Appearing in his letters nearly as frequently was his dramatic appeal for new missionaries and other types of help: spiritual (prayers) and material (money, books and other items useful for his mission). One of his favorite addressees was Fr. Stanisław Czapiewski (1911-2013) who directed a special missionary office in Chicago tasked primarily with helping the African mission of the Polish Jesuits. ${ }^{49}$

Among his myriad outstanding features, the one to highlight is Kozłowiecki's dedication to the African people and his new country. In several letters, he confessed that he liked working with the people, visiting them in their small villages and talking to them, instead of being "chained" to the desk- a circumstance that he sometimes complained about. "Since two months I am chained to the desk and typing machine. I am terribly missing two things: visiting people in villages and teaching at school"11, 1950, while on August 6, 1956 he confessed to another of his fellow Jesuits in Poland: "As far as I am concerned, staying in the villages is not a problem for me. I feel much better here than in Lusaka, and I believe that only those who fear this kind of life have never tried it." 50

He did not say the same, however, about another task that was for a long time his main activity: acting initially as superior of his fellow brothers, and then as apostolic vicar, bishop, and archbishop-wider ecclesiastical structures. As some of his letters indicate, he was not convinced of his ability to do

47 ARSI, Missio Lusakensis 1002-VIII-15. Józef Cudziński, Jesuit from 1921, worked in the curia in ${ }^{1943-58 ~(E n c y k l o p e d i a ~ w i e d z y ~ o ~ j e z u i t a c h, ~ 103) . ~}$

48 Kozłowiecki, Moja Afryka, 338.

49 Stanisław Czapiewski, Jesuit from 1927, from its beginning in 1950, was in charge of that missionary office for thirty-six years, and as such he was in frequent epistolary contact with Kozłowiecki (Encyklopedia wiedzy o jezuitach, 105). 
the job, at the beginning. "I was taken away from the work I liked very much and in which I even, with the grace of God, managed to do something, and I was given a work I dislike and for which I have a feeling that I cannot even do"-he complained to Czapiewski on September 14, 1952, while two weeks later he added, writing to the same addressee: "For me it was easier to write in Kasisi, when I was in the middle of work. Now I am not working myself, but apparently, I am directing the others [...]. I would prefer cleaning chamber pots." ${ }^{51}$ Yet, for many years his main mission involved serving as a leader of others. Only in 1969 did he leave the archbishopric and return to his beloved pastoral work.

Kozłowiecki reconciled his Polish patriotism with his love for Africa. Many times, although he expressed his attachment to his roots, he was concerned about the Polish influence on the mission in Zambia. Yet, when not enough help came from Poland, he was of the opinion that for the good of the mission it should be handed over to others, as long as the local clergy was not strong enough to take control from the foreign missionaries. He was against colonialism and any nationalism and very much in favor of the independencepolitical and ecclesiastical - of his adoptive country. "The Church in Africa demands from Europe to acknowledge the serious changes. A black bishop exercises the authority and leads the work, we come only to help, even to serve the Church in Africa"-he wrote from Rome in 1976.52

On the other hand, he stayed connected to Poland as much as possiblemostly through correspondence - and maintained interest in that nation's affairs, sharing the widespread concern over the problems in 1981, and the hopes that the changes of 1989 had brought. ${ }^{53}$

\section{3}

\section{Hating Hatred}

During a commemorative ceremony that took place on August 25, 1972 in the former concentration camp of Dachau, Kozłowiecki, who was invited to deliver a speech, said: "Here I have learned to hate hatred and to refuse to hate anybody, including even my brother in uniform who hated and tortured me."54 Indeed, the experience of the years spent in the camps shaped the future

51 Grzebień and Kozłowiecki, Wsród ludu Zambii, 2:65, 67.

$5^{2}$ Kozłowiecki, Moja Afryka, 286.

53 Kozłowiecki, Moja Afryka, 307, 329.

54 Stanisław Cieślak, "Ks. arcybiskup Adam Kozłowiecki SJ w obozie koncentracyjnym w Dachau w 1972 roku," Nasza przesztość 127 (2017): 237. An English translation of this speech appeared in Southern African Catholic weekly, The Southern Cross from September $20,1972$. 
missionary and taught him a lot about human beings and about himself. Confronted with the incredibly difficult reality of life under constant humiliation, hunger, stress, and danger, he saw how suffering could break and destroy a person, while others were able to resist it, even at the cost of their lives. In 1940, he vowed in Wiśnicz never to do anything that he might later regret or feel ashamed of: "I only prayed not to do anything wicked or harm other people. I prefer not to come out of this oppression than to survive and be afraid for the rest of my life that somebody will point out something wrong that I have done." ${ }^{55}$ That was certainly one of the most significant choices of his life. The rest of his days were devoted to simply following this resolution.

$55 \quad$ Kozłowiecki, Ucisk i strapienie, 81. 